\author{
Piotr Soroka \\ ORCID: 0000-0002-2316-8717
}

Wyższa Szkoła Bankowa we Wrocławiu

\author{
Magdalena Korkuś-Soroka \\ ORCID: 0000-0001-6052-1228
}

Sąd Rejonowy dla Wrocławia-Śródmieścia we Wrocławiu

DOI: $10.19195 / 1733-5779.28 .25$

\title{
Zastosowanie doktryny „owoców drzewa zatrutego” na gruncie polskiej procedury cywilnej
}

\section{JEL Clasification: K41}

Słowa kluczowe: postępowanie cywilne, postępowanie dowodowe, owoce zatrutego drzewa

Keywords: civil procecure, evidence proceedings, fruit of the poisonous tree

Abstrakt: Artykuł krótko opisuje, czym jest doktryna „owoców drzewa zatrutego” i w jaki sposób może ona wpływać na przebieg procesu cywilnego. Ukazanie tej problematyki na gruncie orzecznictwa pozwala sformułować istotne wnioski, które powinny uwzględniać sądy, w sytuacjach gdy strony próbują wprowadzić do procesu nielegalnie uzyskany dowód. Brak regulacji w tej materii powoduje, że lukę tę musi wypełnić orzecznictwo i doktryna.

\section{Application of the „fruits of the poisonous tree” doctrine in the Polish Civil Procedure}

\begin{abstract}
Polish civil procedure lacks a solution for evidence which was acquired by the parties illegally or in a manner which may stand in collision with good customs or with principles of social coexistence. The "fruit of the poisonous tree" doctrine has roots in criminal procedure but, on the other hand, it could be applied also in civil proceedings (sadly, in Polish criminal procedure this doctrine is very limited). This article is a short presentation of the current views of Polish courts and jurisprudence on this matter, which are not consistent.
\end{abstract}




\section{Wprowadzenie}

Przy okazji kolejnych zmian w postępowaniu karnym powraca kwestia dowodów uzyskanych niezgodnie z prawem. Polskie prawo nie dopuszcza koncepcji „owoców z zatrutego drzewa" (fruits of poisonous tree), polegającej na zakazie uznania za dowód również takiego, który został ujawniony dzięki dowodowi zakazanemu ${ }^{1}$. Problem „owoców drzewa zatrutego” ze względów praktycznych nie może być jednak ograniczany stricte do procedury karnej. W dobie dynamicznych zmian technologicznych i uzyskiwania dostępu do coraz to nowszych sposobów przekazywania i utrwalania danych, zagadnienie to powinno stać się przedmiotem rozważań doktryny cywilistycznej oraz orzecznictwa, które w tej materii jest jednak dość ubogie i niejednoznaczne. Szczególną doniosłość omawiana problematyka może mieć w postępowaniach rodzinnych (zwłaszcza rozwodowych), w których dość częstą sytuacją jest prezentowanie przez strony na przykład korespondencji e-mailowej lub zapisów rozmów w komunikatorach internetowych. Te dowody nie zawsze są uzyskiwane zgodnie z prawem. Problem „owoców zatrutego drzewa" może się pojawiać również w sporach gospodarczych, w których różnego rodzaju dane $\mathrm{i}$ informacje mogą być uzyskiwane w sposób nielegalny (na przykład przez włamania do sieci, przejmowanie serwerów).

\section{Doktryna „owoców drzewa zatrutego"}

Zagadnienie nielegalnych dowodów nie jest problemem nowym. Nie ulega wątpliwości, że zaczynem do naukowej dyskusji były kwestie powstałe na gruncie prawa karnego w państwach anglosaskich. W 1861 roku na jednej ze spraw w Wielkiej Brytanii sędzia miał powiedzieć: „Nieważne jak to [dowód — przyp. aut.] zostało uzyskane; nawet gdyby to było kradzione, byłoby dopuszczalne [jako dowód - przyp. aut.]"2. Pierwotnie zatem sądy w systemie common law odrzucały doktrynę „owoców drzewa zatrutego". Przełomem była sprawa Silverthorne Lumber Co. v. United States z 1920 roku, w której sąd uznał, że nie można dopuścić dowodu uzyskanego na skutek nielegalnego przeszukania ${ }^{3}$. Precedens ten stał się zaczątkiem doktryny „owoców zatrutego drzewa” (fruits of the poisonous tree).

Niewątpliwie problemów w ocenie mogą nastręczać sytuacje ambiwalentne z punktu widzenia moralności, takie jak w sprawie Gäfgen przeciwko Republice Federalnej Niemiec, w której zastosowanie gróźb bezprawnych i przemocy

1 S. Waltoś, Owoce zatrutego drzewa, Kraków 1978, s. 196 n.

2 Cyt. za: N. Cooper, The Fruit of the Poisoned Tree - the Admissability of Evidence in Civil Cases, https://www.bgja.org.uk/wp-content/uploads/2014/02/NigelCooper.pdf?fbclid=IwAR3mc BGDyWiZIuUrvArSDHhCfUCRkTHVgF0E06eyzKVhoh9GigJEt7DYQHs (dostęp: 22.07.2019).

3 Sprawa Silverthorne Lumber Co. Inc. v. United States, 251, U.S., 385 (1920), https://supreme. justia.com/cases/federal/us/251/385/ (dostęp: 22.07.2019). 
w celu zdobycia dowodów miało zapobiec śmierci osób trzecich ${ }^{4}$. W uzasadnieniu wyroku z dnia 1 czerwca 2010 roku Europejski Trybunał Praw Człowieka stwierdził, że naruszenie zakazu wyrażonego w art. 3 Konwencji o ochronie praw człowieka i podstawowych wolności (zakaz tortur) przy przesłuchaniu podejrzanego zasadniczo powinno spowodować wyłączenie z procesu zarówno wyjaśnień złożonych pod przymusem, jak i dowodów rzeczowych uzyskanych dzięki tym wyjaśnieniom, mimo słabszego ich powiązania z naruszeniem art. 3 Konwencji. Jednocześnie jednak Trybunał uznał, że możliwe jest prowadzenie postępowania dowodowego w sprawie karnej na podstawie dowodów uzyskanych pośrednio wskutek nielegalnych metod przesłuchania, o ile dowody te nie mają zasadniczego znaczenia. Pogląd ten został jednakże poddany krytyce przez siedmiu sędziów, którzy we wspomnianej sprawie zgłosili zdanie odrębne, zaznaczając, że w ich ocenie Trybunał nie wykorzystał sposobności do zajęcia jednoznacznego stanowiska $\mathrm{w}$ zakresie standardu postępowania z „owocami z zatrutego drzewa”, to jest wskazania, że w postępowaniu karnym użycie takich dowodów jest niedopuszczalne ${ }^{5}$.

Można wysnuć wniosek, że swoisty stan wyższej konieczności może prowadzić do uznania za legalne nawet dowodów uzyskanych w sposób niezgodny z prawem. Jest to oczywiście przedmiotem kontrowersji, co wyraża się również w treści przytoczonego orzeczenia ETPCz. Nie ulega natomiast wątpliwości, że każde państwo, które chce uchodzić za cywilizowane, powinno dyskwalifikować dowody uzyskane w sposób skrajnie sprzeczny z prawem (na przykład dowody uzyskane w wyniku tortur).

Wydawało się, że w polskim ustawodawstwie karnym zostanie recypowana doktryna „owoców drzewa zatrutego"6. W nowelizacji k.p.k. ${ }^{7}$, która weszła w życie w lipcu 2015 roku, wprowadzono przepis art. 168a, uniemożliwiający przeprowadzenie dowodu uzyskanego dla celów postępowania karnego w wyniku czynu zabronionego w rozumieniu art. $1 \S 1$ k.k. ${ }^{8} \mathrm{Z}$ jednej strony była to zatem zmiana rewolucyjna, wypychała bowiem poza nawias postępowania karnego wszelkie dowody uzyskane w drodze przestępstwa, z drugiej jednak nie dyskwalifikowała dowodów uzyskanych w sposób sprzeczny z prawem (na przykład w sprzeczności z przepisami procedury karnej). W trakcie obowiązywania wspomnianego przepisu Sąd Najwyższy stwierdził jednoznacznie, że art. 168a k.p.k. nie wyklu-

${ }^{4}$ Szerzej na temat sprawy przed ETPCz zob. M. Menkes, Tortury a środki dowodowe w procesie karnym: Sprawa Gäfgen v. Niemcy, „Polski Rocznik Praw Człowieka i Prawa Humanitarnego" 2012, nr 3, s. 265-290

5 Wyrok Europejskiego Trybunału Praw Człowieka z dnia 30 czerwca 2008 roku w sprawie Gäfgen v. Niemcy 22978/05, Legalis nr 130141.

6 Zob. szerzej S. Waltoś, op. cit., s. 23 n.

7 Ustawa z dnia 6 czerwca 1997 roku Kodeks postępowania karnego (tekst jedn. Dz.U. z 2016 r. poz. 1749).

${ }^{8}$ Ustawa z dnia 6 czerwca 1997 roku Kodeks karny (tekst jedn. Dz.U. z 2016 r. poz. 1137). 
cza prowadzenia dowodów nielegalnych, których uzyskanie nie stanowiło czynu zabronionego 9 . Pomimo zatem próby uzyskania przez ustawodawcę efektu zbliżonego do doktryny „owoców drzewa zatrutego” poniósł on legislacyjną porażkę. Abstrahując od motywów kierujących legislaturą, przepis ten uległ szybkiej zmianie, ograniczając katalog przestępstw jedynie do tych popełnionych przez funkcjonariuszy publicznych i to tylko zabójstw, spowodowania umyślnego uszczerbku na zdrowiu lub pozbawienia wolności. Co więcej, wprowadzono także art. 168b, umożliwiający procesowe wykorzystanie dowodów uzyskanych w toku kontroli operacyjnej, niejako przy okazji prowadzenia postępowania co do innego przestępstwa lub przestępstwa skarbowego. Ten przepis w istocie przekreśla krótką i nieudaną historię koncepcji „,owoców drzewa zatrutego” w polskim postępowaniu karnym. Zmiany te należy ocenić krytycznie, gdyż omawiana doktryna to z jednej strony wyraz zaufania obywateli do państwa (i na odwrót), a z drugiej umożliwia obywatelowi skuteczną obronę przed omnipotentnymi działaniami państwa, które jest jego ,przeciwnikiem” w procesie karnym.

Podsumowując zatem tę część rozważań, należy wskazać, że implementacja doktryny „owoców drzewa zatrutego” w polskiej procedurze karnej, nawet w formie przyjętej w 2015 roku, nie miała charakteru całkowitego i takiego jak w prawodawstwie i orzecznictwie w Stanach Zjednoczonych czy Wielkiej Brytanii. Bardzo dobre rozwiązanie zostało przyjęte w art. 78 brytyjskiej ustawy o dowodach policyjnych i kryminalnych ${ }^{10}$. Pozostawia on możliwość dokonania przez sąd samodzielnej oceny, czy dopuszczenie danego dowodu w postępowaniu nie spowodowałoby rażącego naruszenia zasady prawa do sprawiedliwego procesu. Ustawodawca brytyjski słusznie przyznał kompetencję do oceny dowodu sądowi, który na podstawie okoliczności sprawy może uznać dowód zawnioskowany przez oskarżyciela za niedopuszczalny. Sam sąd nie ma zatem możliwości dyscyplinowania organów ścigania, jednak może zapobiegać nadużywaniu władzy z ich strony ${ }^{11}$. Okoliczność ta jednoznacznie wskazuje, jak wielka różnica dzieli polski porządek prawny w tym zakresie od prawa idealnego, tworzonego z myślą o obywatelu i jego prawach.

\section{2. „Owoce drzewa zatrutego" a reguły dowodowe w postępowaniu cywilnym}

Dotychczasowe rozważania skupiły się na ogólnej idei „owoców drzewa zatrutego". Nie ulega wątpliwości, że problematyka ta jest szczególnie doniosła

9 Wyrok Sądu Najwyższego z dnia 2 lutego 2016 roku, sygn. akt IV KK 346/15, Legalis nr 1406413.

10 Art. 78 Police and Crmininal Evidence Act 1984, http://www.legislation.gov.uk/ukpga/1984/60/ section/78 (dostęp: 22.07.2019).

11 Reggina v. Horseferry Road Magistrates' Court, Ex Parte Bennet [1993] (HL), http://swarb. co.uk/regina-v-horseferry-road-magistrates-court-ex-parte-bennett-no-1-hl-24-jun-1993/ (dostęp: 22.07.2019). 
w kontekście postępowań karnych. Jest to oczywiste, gdyż istnienie tej reguły dowodowej ma gwarantować, że państwo nie będzie nadużywać złych praktyk ${ }^{12}$. Nie sposób jednak nie dostrzec, szczególnie w czasie postępu technologicznego, jej wagi w postępowaniu cywilnym, w którym mogą występować dowody uzyskane niezgodnie z prawem.

\subsection{Niedopuszczalność dowodu w postępowaniu cywilnym w państwach anglosaskich}

Ponieważ źródła koncepcji „,owoców drzewa zatrutego” leżą w systemach common law, należy przeanalizować, w jaki sposób tamtejsza doktryna i orzecznictwo radzą sobie z tym problemem na gruncie postępowania cywilnego. Pierwotnie w doktrynie brytyjskiej wskazywano, że co do zasady brakuje ogólnych kryteriów odnoszących się do niedopuszczalności dowodów uzyskanych w sposób sprzeczny $\mathrm{z}$ prawem w postępowaniu cywilnym ${ }^{13}$. W orzecznictwie angielskim przyjęto zaś zasadniczo, że — w przeciwieństwie do postępowań karnych — na gruncie procedury cywilnej sędzia nie ma możliwości zadecydowania, czy dowód dopuścić, czy nie, a zatem nie można dowodu oddalić na podstawie bezprawnego sposobu jego uzyskania ${ }^{14}$. Sytuacja ta się zmieniła po wprowadzeniu Reguł Procedury Cywilnej (CPR) w roku 1998 roku ${ }^{15}$. Artykuł 32 ust. 1 pkt 2 umożliwił sądom oddalanie dowodów jako niedopuszczalnych. Sądy angielskie poddają zatem pod rozwagę, czy dopuszczenie dowodu uzyskanego w sposób sprzeczny z prawem jest konieczne do prawidłowego ustalenia stanu faktycznego. Można wnioskować, że jeżeli bez „zatrutego” dowodu sąd nie mógłby wydać sprawiedliwego wyroku, to jest opartego na właściwych przesłankach faktycznych, to powinien taki dowód dopuścić.

Jeśli zaś chodzi o Stany Zjednoczone, dużą rolę odgrywa tam sposób zachowania się strony, która uzyskuje dowód w sposób nielegalny. Jeżeli jej działania stoją w oczywistej sprzeczności z uczciwością, musi się ona liczyć z tym, że dowód może zostać oddalony ${ }^{16}$. Podobnie rzecz się ma w kwestii dokumentów zastrzeżonych, a ujawnionych omyłkowo. W Stanach Zjednoczonych taki dowód może zostać oddalony, zwłaszcza jeżeli jest to dowód powiązany z tajemnicą, jaka łączy

12 R.M. Pitler, ,, The Fruit of the Poisonous Tree” Revisited and Shepardized, „California Law Review" 56, 1968, s. 587.

13 N. Cooper, op. cit., s. 3.

14 C. Tapper, Cross\&Tapper on Evidence, Oxford-New York 2010, s. 213.

15 Civil Procedure Rules 1998, http://www.legislation.gov.uk/uksi/1998/3132/contents/made (dostęp: 22.07.2019).

16 R.P. Mosteller, Admissibility of Fruits of Breached Evidentiary Privileges: The Importance of Adversarial Fairness, Party Culpability, and Fear of Immunity, „Washington University Law Quarterly" 81, 2003, s. 980-981. 
klienta i jego pełnomocnika ${ }^{17}$. Także w Anglii materiały zastrzeżone uzyskane w sposób przypadkowy nie mogą być dowodem ${ }^{18}$.

\subsection{Artykuł 3 k.p.c. w kontekście oceny dopuszczalności dowodu}

Jak wspomniano, ustawodawca polski już raz próbował dokonać recepcji koncepcji „owoców drzewa zatrutego" na gruncie postępowania karnego, co w istocie nie było udaną próbą. Rozważania dotyczące postępowania cywilnego w tej materii napotykają jednak istotną barierę - w procedurze cywilnej brakuje sprecyzowanych reguł odnoszących się do dowodów uzyskanych w sposób sprzeczny $\mathrm{z}$ prawem.

Zalążek tej idei można dostrzec $\mathrm{w}$ art. 3 k.p.c. ${ }^{19}$ Zgodnie z powołanym przepisem strony i uczestnicy postępowania powinni dokonywać czynności procesowych zgodnie z dobrymi obyczajami, dawać wyjaśnienia co do okoliczności sprawy zgodnie z prawdą i bez zatajania czegokolwiek oraz przedstawiać dowody. Ustawodawca w sferze jednego z trzech ciężarów procesowych wynikających $\mathrm{z}$ art. 3 k.p.c. odwołuje się zatem do działania w procesie zgodnie z klauzulą dobrych obyczajów, nie zaś zgodnie z prawem. Z treści niektórych orzeczeń wydawałoby się jednak, że odnosi się to bardziej do samej czynności niż do jej tre$\mathrm{ści}^{20}$. Zatem wspomnianego przepisu nie powinno się odnosić do oceny dowodu w kontekście jego sprzeczności z dobrymi obyczajami. Na to wskazywałoby także literalne brzmienie przepisu.

Takie stanowisko w przekonaniu autora jest jednak błędne. Wydaje się bowiem, że sąd może ocenić dopuszczalność dowodu przez pryzmat zasad współżycia społecznego i zachowania strony przeciwnej ${ }^{21}$. Może to mieć znaczenie w kontekście prowadzenia postępowania przez sąd, a raczej pewnej „techniki” dopuszczania dowodów. W praktyce można bowiem się spotkać z różnymi działaniami sędziów w zakresie wydawania postanowień dowodowych. Niektórzy sędziowie dopuszczają dowody na bieżąco, czyli decydują o tym bezpośrednio po zawnioskowaniu danego dowodu przez stronę. Inną praktyką spotykaną w polskich sądach jest natomiast pozostawienie tej czynności na koniec procesu i wydawanie postanowień dowodowych przed zamknięciem rozprawy. Zważywszy na treść art. 240

17 Ibidem, s. 981-982.

18 N. Cooper, op. cit., s. 8.

19 Ustawa z dnia 17 listopada 1964 roku Kodeks postępowania cywilnego (tekst jedn. Dz.U. z 2018 r. poz. 1360).

20 Zob. postanowienie Sądu Najwyższego z dnia 21 lipca 2015 roku, III UZ 3/15, Legalis nr 1360221.

${ }^{21}$ Zob. na przykład uzasadnienie wyroku Sądu Okręgowego w Lublinie z dnia 30 stycznia 2014 roku, II Ca 848/13, Legalis nr 1575916; w tej sprawie sąd dopuścił dowód z nagrania uzyskanego bez wiedzy osoby nagrywanej, wskazując, że skoro strona sama zeznawała niezgodnie z prawem, to nie powinna powoływać się na niezgodność z dobrymi obyczajami dowodu uzyskanego także w taki sposób. 
$\S 1$ k.p.c., wydaje się to irrelewantne, jednak biorąc pod uwagę przebieg procesu, może to mieć znaczenie dla stron. W kontekście kolejnych ujawnianych w toku rozprawy dowodów sąd może dojść do przekonania, że któryś z tych dowodów powinien zostać uznany za niedopuszczalny lub nie. Zgodnie z przytoczonym stanowiskiem dopiero na podstawie całokształtu dowodów możliwa jest ocena, czy dany dowód powinien być dopuszczony przez sąd.

W orzecznictwie problematyka wykorzystywania dowodów zebranych metodami niezgodnymi z prawem jest różnie pojmowana. Podkreślenia jednakże wymaga, że sąd orzekający każdorazowo powinien wziąć pod uwagę okoliczności konkretnej sprawy i całokształt materiału dowodowego zgromadzonego w sprawie, rozważnie podchodząc do tez orzecznictwa, które wydane zostały przecież na gruncie różnorodnych stanów faktycznych. W wyroku z dnia 25 kwietnia 2003 roku Sąd Najwyższy, oceniając dowód z nagrań rozmów telefonicznych w sprawie o rozwód, stwierdził, że

nie ma zasadniczych powodów do całkowitej dyskwalifikacji kwestionowanego przez pozwaną dowodu z nagrań rozmów telefonicznych, nawet jeżeli nagrań tych dokonywano bez wiedzy jednego z rozmówców. Skoro strona pozwana nie zakwestionowała skutecznie w toku postępowania autentyczności omawianego materiału, to mógł on służyć za podstawę oceny zachowania się pozwanej w stosunku do pozwanego i możliwości sformułowania wniosku o nadużywaniu alkoholu przez pozwaną ${ }^{22}$.

W orzecznictwie prezentowane jest także stanowisko odmienne ${ }^{23}$. Zgodnie z nim strona nie może posuwać się do czynności podstępnych czy sprzecznych z zasadami współżycia społecznego. Wczytując się jednak dokładnie w uzasadnienie przytoczonego wyroku Sądu Apelacyjnego w Warszawie, można dostrzec, że sąd powinien oceniać ewentualną dopuszczalność dowodu przez pryzmat całokształtu materiału dowodowego. Nie można zatem a priori zakładać, że dowód uzyskany w sposób sprzeczny z prawem będzie uznany za niedopuszczalny.

Jeszcze bardziej zachowawcze stanowisko prezentuje w tej materii Sąd Apelacyjny w Poznaniu ${ }^{24}$. W jednym ze swych rozstrzygnięć stwierdził on bowiem, że dowód uzyskany w sposób bezprawny co do zasady nie powinien być dopuszczony w postępowaniu. Zdaniem tego sądu podstępnie uzyskane nagranie godzi w konstytucyjną zasadę ochrony i swobody komunikowania się. Jednocześnie sąd, posługując się sformułowaniem ,co do zasady”, zostawia otwartą furtkę do wprowadzenia dowodu uzyskanego sprzecznie z prawem do procesu.

22 Zob. wyrok Sądu Najwyższego - Izba Cywilna z dnia 25 kwietnia 2003 roku, IV CKN 94/01, Legalis nr 62099.

23 Zob. wyrok Sądu Apelacyjnego w Warszawie, z dnia 6 lipca 1999 roku, I ACa 380/99, Legalis $\mathrm{nr} 48547$.

24 Zob. uzasadnienie wyroku Sądu Apelacyjnego w Poznaniu z dnia 10 stycznia 2008 roku, I Aca 1057/07, Legalis nr 180032. 
Odmienne stanowisko niż przedstawione zajął Sąd Apelacyjny w Krakowie:

nagrywanie innej osoby bez poinformowania o utrwalaniu rozmowy powoduje, że tak uzyskane nagranie nie może być dowodem w sprawie i stanowi czyn nielojalny w stosunku do rozmówcy, w tym przypadku współmałżonka. Uzyskanie nagrania przed powstaniem trwałego rozkładu pożycia w taki sposób skutkuje przyjęciem zawinienia tak postępującego małżonka ${ }^{25}$.

Kwestia dopuszczalności użycia w postępowaniu cywilnym dowodu uzyskanego w sposób bezprawny pojawia się oczywiście nie tylko w sprawach rozwodowych. Przywołane stanowisko Sądu Najwyższego służyło sądom powszechnym na przykład w sprawie o zapłatę. Sąd Apelacyjny w Białymstoku trafnie zwrócił uwagę na możliwość zaistnienia konfliktu pomiędzy wartościami konstytucyjnymi, to jest prawem od sprawiedliwego procesu (art. 45 Konstytucji RP), w czym zawiera się również proces zgodny z prawdą, a wolnością i ochroną tajemnicy komunikowania się (art. 49 Konstytucji RP). Mając to na względzie, sąd ten podkreślił, że „trudno jest wyartykułować w omawianej kwestii generalną dyrektywę, która znajdzie zastosowanie we wszystkich przypadkach, a zapewne nie jest to w ogóle możliwe" 26 .

\subsection{Przedmiot dowodu a jego dopuszczalność}

Zgodnie z art. 227 k.p.c. dowodem może być fakt istotny dla rozstrzygnięcia sprawy. Kodeks postępowania cywilnego nie formułuje zamkniętego katalogu środków dowodowych. Dowodem może być zatem przesłuchanie świadka, nagranie głosu, utrwalenie obrazu czy też rzecz ruchoma. Ustawodawca nie sformułował też, czy ze względu na swój charakter dany dowód nie może być dopuszczony. Wyjątkiem są przepisy związane z przesłuchaniem świadków, które wskazują wprost, kto nie może być świadkiem lub może się uchylić od zeznawania (art. 259-261 k.p.c.). Sam charakter dowodu nie może powodować niedopuszczalności dowodu a priori. Decyduje zatem uznanie sądu, że dany środek dowodowy może przyczynić się do rozstrzygnięcia sprawy. Ustawa nie dyskwalifikuje dowodu uzyskanego w sposób sprzeczny z prawem lub z zasadami współżycia społecznego. Nie decyduje tu jednak sam charakter dowodu - czy jest to rzecz, zeznanie świadka czy dokument, lecz to, w jaki sposób ten dowód został uzyskany. Najczęściej jednak dowodami uzyskanymi w sposób sprzeczny z prawem będą różnego rodzaju nagrania lub utrwalenia obrazu. Nie wyklucza to jednak możliwości uzyskania innego dowodu nielegalnie. Taką ,skazą" mogą być obciążone zeznania świadka, który został zastraszony lub przekupiony przez stronę. Innym przykładem może być wykradziony przez stronę dokument czy dokument sfałszowany.

25 Zob. wyrok Sądu Apelacyjnego w Krakowie z dnia 21 listopada 2013 roku, I ACa 1122/13, Legalis nr 1002326.

26 Zob. wyrok Sądu Apelacyjnego w Białymstoku z dnia 31 grudnia 2012 roku, I ACa 504/11, Legalis nr 665846. 
Na tych przykładach widać, że istota „owocu drzewa zatrutego” nie sprowadza się do tego, czym ten dowód jest, ale do tego, w jaki sposób dowód został uzyskany, a następnie wprowadzony do procesu.

\subsection{Reguła „owoców drzewa zatrutego” w kontekście wznowienia postępowania cywilnego}

O „owocach drzewa zatrutego” będziemy mówić w wypadku, gdy jedna ze stron postępowania cywilnego posługuje się dowodem uzyskanym na skutek przestępstwa. Może zatem pojawić się pytanie, czy jeżeli sąd dopuszcza dowód, którym jest przykładowo nielegalnie uzyskana korespondencja mailowa, nie działa sprzecznie z istotą przepisów o wznowieniu postępowania cywilnego.

Należy wskazać, że zgodnie z art. 267 § 1 k.k. przestępstwem jest uzyskanie informacji nieprzeznaczonej dla sprawcy, przy czym warunkiem jest tu pokonanie zabezpieczenia, na przykład informatycznego. Takim zabezpieczeniem może być kod lub hasło ${ }^{27}$. Mąż włamujący się do skrzynki mailowej żony, bez jej wiedzy, w celu uzyskania informacji o jej zdradzie, dopuszcza się bez wątpienia czynu opisanego we wskazanym przepisie. Co zatem powinien zrobić sąd, gdy jedna ze stron postępowania przedstawia w toku procesu taki dowód? Przede wszystkim i należy zwrócić uwagę na art. 404 k.p.c. Zgodnie z tym przepisem jeżeli postępowanie ma zostać wznowione na tej podstawie, że wyrok został wydany na podstawie przestępstwa, to niezbędny jest prawomocny wyrok karny lub ewentualnie inne orzeczenia stwierdzające fakt popełnienia przestępstwa (na przykład postanowienia o umorzeniu postępowania z powodu przedawnienia karalności). Fakt powstania tego orzeczenia będzie miał zwykle miejsce po zakończeniu postępowania cywilnego (choć oczywiście nie zawsze). W przekonaniu autora, jeżeli już w momencie trwania postępowania cywilnego istnieje karny wyrok stwierdzający, że doszło do popełnienia przestępstwa przy uzyskaniu dowodu, to sąd nie powinien dopuszczać takiego dowodu z uwagi na przepis art. $403 \S 1$ pkt 2 k.p.c. Skoro bowiem stanowi to podstawę do wznowienia postępowania, znaczy to, że ustawodawca negatywnie ocenia oparcie się na dowodzie, który pochodzi z przestępstwa. Ponadto należy pamiętać, że sąd cywilny jest związany wyrokami karnymi na podstawie art. 11 k.p.c. Wówczas sąd nie może zakwestionować okoliczności, że do przestępstwa doszło, a dowód stanowi „owoc” czynu zabronionego.

Inaczej należy rozpatrywać sytuację, jeśli w toku postępowania cywilnego nie ma rozstrzygnięcia sądu karnego. Sąd cywilny zatem sam ocenia, zgodnie z regułami oceny dowodów, czy taki dowód jest dopuszczalny. Należy mieć zawsze na względzie, że niektóre przestępstwa są ścigane na wniosek, a brak wniosku uniemożliwia wydanie wyroku skazującego. Sąd więc powinien wykazać daleko

27 Zob. Kodeks karny. Komentarz, red. R. Stefański, Warszawa 2017, komentarz do art. 267 teza III.8. 
idącą ostrożność, oceniając dowód pochodzący z przestępstwa. Z jednej strony może bowiem być on jedyną ścieżką do ustalenia prawdy materialnej, a z drugiej w razie postępowania karnego może oznaczać otwartą drogę do wznowienia postępowania. Jednak w tej materii warto przywołać stanowisko Sądu Najwyższego wyrażone w jednej ze $\operatorname{spraw}^{28}$. W postanowieniu Sąd Najwyższy wskazał, że jeżeli jakaś okoliczność (w tamtej sprawie fałszerstwo dokumentu) była badana przez sąd i nie została uznana za niezasadną, to nie można na tej podstawie żądać wznowienia postępowania. Pojawia się jednak wątpliwość, czy wniosek ten będzie prawidłowy, gdy ta okoliczność zostanie stwierdzona prawomocnym wyrokiem karnym. Wydaje się, że nie i przesłanka uzyskania wyroku w wyniku przestępstwa wówczas zaktualizuje się.

\subsection{Reakcja sądu na wprowadzenie do procesu owoców drzewa zatrutego}

Oprócz decyzji sądu, czy dowód stanowiący „owoc drzewa zatrutego” może zostać dopuszczony, sąd powinien rozważyć kwestię ewentualnego poinformowania organów ścigania o podejrzeniu popełnienia przestępstwa. Jak wspomniano, procedura cywilna nie reguluje materii „owoców drzewa zatrutego”, dlatego brakuje takich przepisów, które nakazywałyby sądowi podjęcie działania (poza podjęciem postanowienia dowodowego o dopuszczeniu lub nie dowodu). Ewentualne działania sądu mogą natomiast wynikać z obowiązku sformułowanego w art. $304 \S 2$ k.p.k. Przepis ten nakłada na instytucje państwowe i samorządowe obowiązek powiadomienia prokuratora lub policji, gdy w związku ze swoim funkcjonowaniem ujawnią one fakt popełnienia przestępstwa. Jeżeli zatem sąd dochodzi do przekonania, że strona uzyskała jakiś dowód w sposób przestępczy, powinien podjąć działania wynikające ze wskazanego przepisu. W praktyce wymiaru sprawiedliwości są to jednak sytuacje rzadkie.

\section{Podsumowanie - uwagi de lege ferenda i de lege lata}

Podsumowując całość rozważań, należy zwrócić uwagę, że powierzenie sądowi nieograniczonej swobody w dopuszczaniu dowodów, w tym takich, które zostały uzyskane w wyniku przestępstwa, nie jest właściwe. Rozbieżności w orzecznictwie sądów wskazują, że ustawodawca powinien rozwiązać tę sytuację, wprowadzając do kodeksu postępowania cywilnego odpowiednie przepisy. Zdaniem autora zasadne jest ustanowienie zakazu dowodowego, uniemożliwiającego stronom wprowadzanie do postępowania dowodów uzyskanych w sposób sprzeczny z prawem. Jednocześnie jednakże należałoby pozostawić sądowi możliwość dopuszczenia takowego dowodu w wyjątkowych sytuacjach, w których jego oddalenie mogłoby doprowadzić do rozstrzygnięcia w sposób oczywiście sprzeczny

28 Zob. postanowienie Sądu Najwyższego z dnia 2 grudnia 2011 roku, sygn. akt III CZ 69/11, Legalis nr 496976. 
z zasadami współżycia społecznego. Taka regulacja byłaby dla sądu i stron sygnałem, że co do zasady wniosek dowodowy zostanie oddalony, chyba że strona wykaże, że z uwagi na szczególne okoliczności nie ma innej drogi do ustalenia stanu faktycznego, który zaistniał w rzeczywistości.

Obecne rozbieżne orzecznictwo nie sprzyja pewności prawa, jednakże w przekonaniu autora sądy powinny skłaniać się raczej ku stanowisku rygorystycznemu, które nie dopuszcza wprowadzania do postępowania dowodów uzyskanych w sposób sprzeczny z prawem, w szczególności zaś będących pokłosiem popełnionego przez stronę przestępstwa. Za dopuszczeniem tego typu dowodów powinny przemawiać wyłącznie wyjątkowe okoliczności danej sprawy.

\section{Bibliografia}

Kodeks karny. Komentarz, red. R. Stefański, Warszawa 2017.

Menkes M., Tortury a środki dowodowe w procesie karnym. Sprawa Gäfgen v. Niemcy, „Polski Rocznik Praw Człowieka i Prawa Humanitarnego" 2012, nr 3.

Mosteller R.P., Admissibility of Fruits of Breached Evidentiary Privileges: The Importance of Adversarial Fairness, Party Culpability, and Fear of Immunity, ,Washington University Law Quarterly" 81, 2003.

Pitler R.M., “The Fruit of the Poisonous Tree” Revisited and Shepardized, „California Law Review" 56, 1968.

Tapper C., Cross\&Tapper on Evidence, Oxford-New York 2010.

Waltoś S., Owoce zatrutego drzewa, Kraków 1978.

\section{Akty prawne}

Ustawa z dnia 17 listopada 1964 roku Kodeks postępowania cywilnego, tekst jedn. Dz.U. z 2018 r. poz. 1360.

Ustawa z dnia 6 czerwca 1997 roku Kodeks karny, tekst jedn. Dz.U. z 2016 r. poz. 1137.

Ustawa z dnia 6 czerwca 1997 roku Kodeks postępowania karnego, tekst jedn. Dz.U. z 2016 r. poz. 1749.

\section{Orzeczenia}

Postanowienie Sądu Najwyższego z dnia 2 grudnia 2011 roku, sygn. akt III CZ 69/11, Legalis nr 496976.

Postanowienie Sądu Najwyższego z dnia 21 lipca 2015 roku, sygn. akt III UZ 3/15, Legalis nr 1360221.

Wyrok Europejskiego Trybunału Praw Człowieka z dnia 30 czerwca 2008 roku w sprawie Gäfgen v. Niemcy 22978/05, Legalis nr 130141.

Wyrok Sądu Apelacyjnego w Warszawie z dnia 6 lipca 1999 roku, I ACa 380/99, Legalis nr 48547.

Wyrok Sądu Apelacyjnego w Poznaniu z dnia 10 stycznia 2008 roku, I Aca 1057/07, Legalis nr 180032.

Wyrok Sądu Apelacyjnego w Białymstoku z dnia 31 grudnia 2012 roku, I ACa 504/11, Legalis nr 665846.

Wyrok Sądu Apelacyjnego w Krakowie z dnia 21 listopada 2013 roku, I ACa 1122/13, Legalis nr 1002326.

Wyrok Sądu Najwyższego z dnia 25 kwietnia 2003 roku, IV CKN 94/01, Legalis nr 62099. 
Wyrok Sądu Okręgowego w Lublinie z dnia 30 stycznia 2014 roku, II Ca 848/13, Legalis nr 1575916. Wyrok Sądu Najwyższego z dnia 2 lutego 2016 roku, sygn. akt IV KK 346/15, Legalis nr 1406413.

\section{Źródła internetowe}

Civil Procedure Rules 1998, http://www.legislation.gov.uk/uksi/1998/3132/contents/made.

Cooper N., The Fruit of the Poisoned Tree - the Admissability of Evidence in Civil Cases, https:// www.bgja.org.uk/wp-content/uploads/2014/02/NigelCooper.pdf?fbclid=IwAR3mcBGDyWiZI uUrvArSDHhCfUCRkTHVgF0E06eyzKVhoh9GigJEt7DYQHs.

Police and Crmininal Evidence Act 1984, http://www.legislation.gov.uk/ukpga/1984/60/section/78. Reggina v. Horseferry Road Magistrates' Court, Ex Parte Bennet [1993] (HL), http://swarb.co.uk/ regina-v-horseferry-road-magistrates-court-ex-parte-bennett-no-1-hl-24-jun-1993/.

Sprawa Silverthorne Lumber Co. Inc. v. United States, 251, U.S., 385 (1920), https://supreme.justia. $\mathrm{com} / \mathrm{cases} /$ federal/us/251/385/.

\section{Application of the "fruit of the poisonous tree" doctrine in the Polish Civil Procedure}

\section{Summary}

The paper presents a short characteristic of the "fruit of the poisonous tree" doctrine and how it can influence civil procedure. Description of this matter on the ground of court rulings and views of law doctrine can be a basis for crucial conclusions, which should be taken into account by courts in situations in which parties of litigation are trying to introduce evidence which had been acquired illegally. Lack of regulation in that matter means that this gap must be filled by jurisprudence and judicature. 